https://nv.nltu.edu.ua

https://doi.org/10.36930/40300103

$@ \bowtie$ Correspondence author

Article received 10.12.2019 p.

Article accepted 27.02.2020 p.

V. V. Monarkh

UDK 712.4

В. В. Монарх

Вінницький національний аграрний університет, м. Вінниия, Україна

\title{
АНАЛІЗ АСОРТИМЕНТУ РОСЛИН ОРАНЖЕРЕЇ БОТАНІЧНОГО САДУ "ПОДІЛЛЯ" ВІННИЦЬКОГО НАЦІОНАЛЬНОГО АГРАРНОГО УНІВЕРСИТЕТУ
}

Доведено, що місцем, відведеним під озеленення приміщення, в якому на обмеженій площі розміщено екзотичні рослини в поєднанні з водними пристроями та малими архітектурними формами, є оранжерея Ботанічного саду "Поділля" Вінницького національного аграрного університету. Її основне призначення є не тільки естетичне задоволення гостей та жителів міста, відпочинок на природі в будь-який сезон року, а й розмноження та інтродукція видів рослин інших кліматичних зон. Вперше проведено сучасну оцінку асортименту рослин оранжереї Ботанічного саду "Поділля" ВНАУ, відповідно до якої в оранжереї нараховують 44 родини, 88 родів та 94 види рослин. Висвітлено, що головним компонентом оранжереї $\epsilon$ види, що належать до різних родин та відрізняються за вимогами, необхідними для їх росту та розвитку. Асортимент видів, представлених в оранжереї, є надзвичайно широкий. Встановлено, що рослини за вимогами до місцезростання належать до різних кліматичних зон. Тому для їх декоративності та відмінного росту в оранжереї необхідним є створення відповідним умов. Досліджено, що рослини різних природних ареалів зростання розташовані в оранжереї хаотично без дотримання певного порядку чи систематики. Види інтродуцентів, які $є$ в оранжереї ботанічного саду різняться за відношенням до температури, прийнятної для їх нормального росту і розвитку, тому і розміщувати їх варто групами чи колекціями, наприклад: зона рослин тропіків, зона рослин субтропіків, зона рослин сухих субтропіків, зона рослин Середземномор'я та зона рослин Азії. Враховуючи встановлену малу кількість представників рослин сухих субтропіків в оранжереї ботанічного саду, обов'язковим $€$ поповнення колекції сукулентів та створення флораріуму і кактусарію.

Ключові слова: зимовий сад; інтродуцент; ареал; інвентаризація; об'єкт.

Вступ. На території Вінницької обл. поряд з туристично відомими пам'ятками архітектури розташована установа науково-дослідницького та культурно-просвітницького характеру; заклад, в якому зібрано колекції деревних і чагарникових видів рослин різних кліматичних зон; місце культивування, збереження й акліматизації перспективних для створення зелених насаджень в озелененні міста видів рослин. Цим об'єктом є Ботанічний сад "Поділля", що розташований на території Вінницького національного аграрного університету [5].

Місцем, відведеним під озеленення приміщення, в якому на обмеженій площі розміщено понад 90 видів екзотичних рослин, доповненням до композиції яких $\epsilon$ декоративний ставок, $є$ оранжерея, розташована на території ботанічного саду. Ї̈̈ основне призначення $є$ не тільки естетичне задоволення гостей та жителів міста та відпочинок на природі в будь-який сезон року, а й розмноження та інтродукція видів рослин інших кліматичних зон [1].

Об'єктом дослідження є оранжерея Ботанічного саду "Поділля" ВНАУ.

Предметом дослідження є методи і засоби аналізу асортименту рослин оранжереї Ботанічного саду "Поділля" Вінницького національного аграрного університету.
Мета дослідження полягає в проведенні аналізу асортименту рослин оранжереї Ботанічного саду "Поділля". Для досягнення мети потрібно виконати такі основні завдання дослідження:

- провести таксономічний аналіз асортименту рослин оранжереї Ботанічного саду "Поділля";

- розподілити наявний сортимент рослин відповідно до природного ареалу поширення;

- згрупувати рослини оранжереї за кліматичними зонами;

- внести пропозиції щодо покращення розташування рослин в оранжереї.

Наукова новизна дослідження полягає в тому, що вперше проведено сучасну оцінку асортименту рослин оранжереї Ботанічного саду "Поділля" Вінницького національного аграрного університету.

Практична значущість отриманих результатів полягає в тому, що рослини, які зростають в оранжереї ботанічного саду залежно від їхнього відношення до температурного режиму, характерних кліматичних зон, пропонуємо розміщувати групами чи колекціями: тропічні, субтропічні, сухі субтропіки, рослини Середземномор'я, рослини Азії. Враховуючи виявлену малу кількість видів та родів, природний ареал поширення яких $\epsilon$ сухі субтропіки в оранжереї ботанічного саду, обов'язковим є поповнення колекції сукулентів та створення флораріуму і кактусарію.

\section{Інформація про авторів:}

Монарх Вероніка Валентинівна, канд. с.-г. наук, ст. викладач, кафедра садово-паркового господарства, садівництва та виноградарства. Email: monarhinya@ukr.net; https://orcid.org/0000-0002-4473-7683

Цитування за ДСтУ: Монарх В. В. Аналіз асортименту рослин оранжереї Ботанічного саду "Поділля" Вінницького національного аграрного університету. Науковий вісник НЛтУ України. 2020, т. 30, № 1. С. 19-24.

Citation APA: Monarkh, V. V. (2020). Analysis of the assortment of plant orangery of the Podillia Botanical Garden of Vinnytsia National Agrarian University. Scientific Bulletin of UNFU, 30(1), 19-24. https://doi.org/10.36930/40300103 
Аналіз літературних джерел. У своїх працях Крижанівська Н. Я. зазначає те, що зимовий сад є середовищем, сформованим штучно 3 використанням конструктивних елементів ландшафтного, флористичного дизайну, фітодизайну та $є$ місцем відпочинку людей в різного характеру приміщеннях. Автор зазначає, що саме зеленим насадженням відводиться головна роль під час формування зимових садів. Окрім цього, рослини не обов'язково мають бути живими або натуральними, адже такого роду об'єкти можна формувати з використанням штучних квітів, які є значно дешевшими щодо купівлі та утримання, ніж композиції із живих рослин [3].

За В. П. Кучерявим [4], композиційна організація зимового саду виражається в розміщенні рослинних угрупувань, водних пристроїв, геопластики в певному просторі з виявленням його стилістики - ландшафтно-декоративної або архітектурно-ландшафтної. Як стверджує Е. В. Ермолова, ландшафтно-декоративна стилістика характеризує створення середовища 3 імітацією природного ландшафту - пустельного, степового, лісового, гірського тощо. Влаштування просторово-предметного середовища відповідно до архітектурної та ландшафтної стилістики зазвичай відбувається з використанням символіки, характерної для тієї чи іншої країни - Японії, Китаю, Англії тощо, а також за дотримання стилів архітектури, найпопулярнішими з яких є: бароко, класицизм, модерн та багато інших [2].

Кожен створений зимовий сад $\epsilon$ унікальним і неповторним у своєму архітектурно-художньому рішенні. Обов'язковим під час створення $є$ знання композиції та дотримання всіх правил побудови такого роду об'єктів. В. Рой [6] рекомендує для досягнення художньої виразності саду керуватися прийомами імітації природного ландшафту. Невеликий зимовий сад може нагадувати глядачу чи відвідувачу "ліс середньої смуги", "вологі тропіки" або "мікроландшафт пустелі з кактусами".

Наявність у зимовому саду тих чи інших конструктивних елементів залежить від його основного функціонального призначення. В якій установі буде розташований, яка вікова категорія людей $є$ його відвідувачами (діти, молодь, доросле населення або пенсіонери)? Це основні питання, на які варто відповісти, перш ніж братися за проектування зимового саду. Адже те, що цікаво у зимовому саду дітям, може не вразити дорослих $[8,7]$.

Результати дослідження та їх обговорення. Види рослин, що належать до різних родин, є складовою частиною будь-якої оранжереї. Враховуючи той факт, що рослини, які зростають у приміщенні, привезли з різних країн, тому і температурний режим для кожного виду характерний свій, відповідно до природного ареалу походження. Рослини різних кліматичних зон потрібно розміщати окремо. Обов'язковим є контроль за дотриманням мікроклімату середовища життя для нормального росту інтродуцентів.

Виконавши докладну оцінку асортименту дослідженого об'єкта, встановлено, що на території оранжереї Ботанічного саду "Поділля" зростає 94 види рослин. Результати дослідження колекції рослин оранжереї наведено у табл. 1.

Найбільшу кількість родів має родина Ароїдні (Araceae), iз 7 родів наявні види: Філодендрон адамантовий (Philodendron adamantinum Mart. ex Schott), Колоказія водяна (Colocasia esculenta var. fontanesii), Сциндапcyc (Scindapsus), Аглаонема крапчата (Aglaonema com- mutatum), Калла ефіопська (Zantedeschia aethiopica), Монстера коса (Monstera obliqua), Спатіфіллум квітучий (Spathiphyllum floribundum).

Табл. 1. Результати оцінювання асортименту колекції рослин оранжереї

\begin{tabular}{|c|c|c|c|}
\hline \multirow{2}{*}{$\begin{array}{l}№ \\
\text { 3/ח }\end{array}$} & \multirow{2}{*}{ Назва родини } & \multicolumn{2}{|c|}{ Кількість } \\
\hline & & родів & видів \\
\hline 1 & Мальвові (Malvaceae) & 2 & 2 \\
\hline 2 & Холодкові (Asparagaceae) & 6 & 6 \\
\hline 3 & Бегонієві (Begoniaceae) & 1 & 1 \\
\hline 4 & Кизилові (Согпасеае) & 1 & 1 \\
\hline 5 & Аралієві (Araliaceae) & 2 & 2 \\
\hline 6 & Рутові (Rutaceae) & 4 & 4 \\
\hline 7 & Ебенові (Ebenaceae) & 1 & 1 \\
\hline 8 & Липові (Tiliaceae) & 1 & 1 \\
\hline 9 & Самшитові (Buxaceae) & 1 & 1 \\
\hline 10 & Асфоделові (Asphodelacea) & 1 & 1 \\
\hline 11 & Пальмові (Arecaceae) & 2 & 2 \\
\hline 12 & Ароїдні (Araceae) & 7 & 7 \\
\hline 13 & Шовковицеві (Moraceae) & 1 & 3 \\
\hline 14 & Геранієві (Geraniaceae) & 2 & 3 \\
\hline 15 & Давалієві (Davalliaceae) & 1 & 1 \\
\hline 16 & Ясноткові (Lamiaceae) & 2 & 2 \\
\hline 17 & Амарилісові (Amaryllidaceae) & 5 & 5 \\
\hline 18 & Агавові (Agavaceae) & 2 & 2 \\
\hline 19 & Зозулинцеві (Orchidaceae) & 1 & 1 \\
\hline 20 & Маслинові (Oleaceae) & 1 & 1 \\
\hline 21 & Кропив'яні (Urticaceae) & 2 & 2 \\
\hline 22 & Барвінкові (Аросупасеае) & 2 & 2 \\
\hline 23 & Акантові (Acanthaceae) & 3 & 3 \\
\hline 24 & Кипарисові (Cupressaceae) & 2 & 2 \\
\hline 25 & Бананові (Musaceae) & 1 & 1 \\
\hline 26 & Лаврові (Lauraceae) & 2 & 2 \\
\hline 27 & Бігнонієві (Bignoniaceae) & 3 & 3 \\
\hline 28 & Комелінові (Commelinaceae) & 5 & 6 \\
\hline 29 & Перцеві (Piperaceae) & 1 & 1 \\
\hline 30 & Павловнієві (Paulowniaceae) & 1 & 1 \\
\hline 31 & Розові (Rosaceae) & 1 & 1 \\
\hline 32 & Бромелієві (Bromeliaceae) & 4 & 4 \\
\hline 33 & Кактусові (Cactaceae) & 2 & 2 \\
\hline 34 & Губоцвіті (Lamiaceae) & 1 & 1 \\
\hline 35 & Стрелітцієві (Strelitziaceae) & 1 & 1 \\
\hline 36 & Товстолисті (Crassulaceae) & 3 & 3 \\
\hline 37 & Дербеникові (Lythraceae) & 1 & 1 \\
\hline 38 & Ксантореєві (Xanthorrhoeaceae) & 2 & 2 \\
\hline 39 & Лілійні (Liliaceae) & 1 & 1 \\
\hline 40 & Миртові (Myrtaceae) & 1 & 1 \\
\hline 41 & Молочайні (Euphorbiaceae) & 2 & 2 \\
\hline 42 & Бобові (Fabaceae) & 1 & 1 \\
\hline 43 & Бальзаминові (Balsaminaceae) & 1 & 1 \\
\hline 44 & Виноградові (Vitaceae) & 1 & 3 \\
\hline & Всього & 88 & 94 \\
\hline
\end{tabular}

Родина Холодкові (Asparagaceae) представлена 6-ма родами. Серед видів в оранжереї зростають такі (рис. 1): Аспідістра висока (Aspidistra elatior Variegata), Холодок лікарський (Asparagus officinalis L.), Агава американська (Agave americana L.), Юкка нитчаста (Yucca filamentosa), Драцена канарська (Dracaena draco), Хлорофітум хохлатий (Chlorophytum comosum).

Нагадаємо, що Вінницький ботанічний сад Поділля був заснований в травні 1963 р. за проектом доктора біологічних наук, професора Паламарчука Анатолія Семеновича та кандидата сільськогосподарських наук, доцента Паламарчук Галини Леонідівни. Ще тоді сад займає 60 га на берегах р. Вишні рядом з меморіальним музеєм М. І. Пирогова. 
Основною метою, яка була поставлена перед ботанічним садом, - вивчення рослинних ресурсів Поділля i рослин для раціонального їх використання. Ботанічний сад мав стати науково-пропагандистським центром, де науковці мали знайомитись 3 рослинним світом, багатством рідного краю і походженням рослин, а також 3 проблемами ботаніки, краєзнавства та досягненням біологічної науки.

Здебільшого родини представлені в оранжереї лише одним родом, наприклад: Бегонієві (Begoniaceae) - Бегонія (Begonia L.), Кизилові (Coгnaceae) - Аукуба (Aucuba), Ебенові (Ebenaceae) - Хурма (Diospyros), Липові (Tiliaceae) - Спарманія (Sparmannia), Самшитові (Buxaceae)- Самшит (Buxus), Асфоделові (Asphodelacea)Алое (Aloe), Бананові (Musaceae) - Банан (Musa), Давалієві (Davalliaceae) - Нефролепіс (Nephrolepis), Зозулинцеві (Orchidaceae) - Каттлея (Cattleya), Маслинові (Oleaceae) - Бірючина (Ligustrum), Перцеві (Piperaсеае) - Пеперомія (Peperomia), Павловнієві (Paulowniaceae) - Павловнія (Paulownia) або Адамове дерево, Розові (Rosaceae) - Шиповник (Rosa), Губоцвіті (Lamiaceae) - Колеус (Coleus), Стрелітцієві (Strelitziaceae)Стрелітція (Strelitzia), Дербеникові (Lythraceae) - Гранат (Granatum), Лілійні (Liliaceae) - Рускус (Ruscus), Миртові (Myrtaceae) - Каллістемон (Callistemon), Бобові (Fabaceae) - Цезальпінія (Caesalpinia), Бальзамінові (Balsaminaceae) - Бальзамін (Impatiens). Загалом в оранжереї нараховують 44 родини, 88 родів та 94 види. Розподіл асортименту рослин оранжереї за ареалом поширення наведено нижче (табл. 2).

Досліджено, що рослини різних природних ареалів зростання розташовані в оранжереї хаотично, без дотримання певного порядку чи систематики. Види інтродуцентів, які $\epsilon$ в оранжереї ботанічного саду, різняться за відношенням до температури, прийнятної для їх нормального росту і розвитку, тому і розміщувати їх варто групами чи колекціями, наприклад: зона рослин тропі- ків, зона рослин субтропіків, зона рослин сухих субтропіків, зона рослин Середземномор'я та зона рослин Азії (табл. 3).

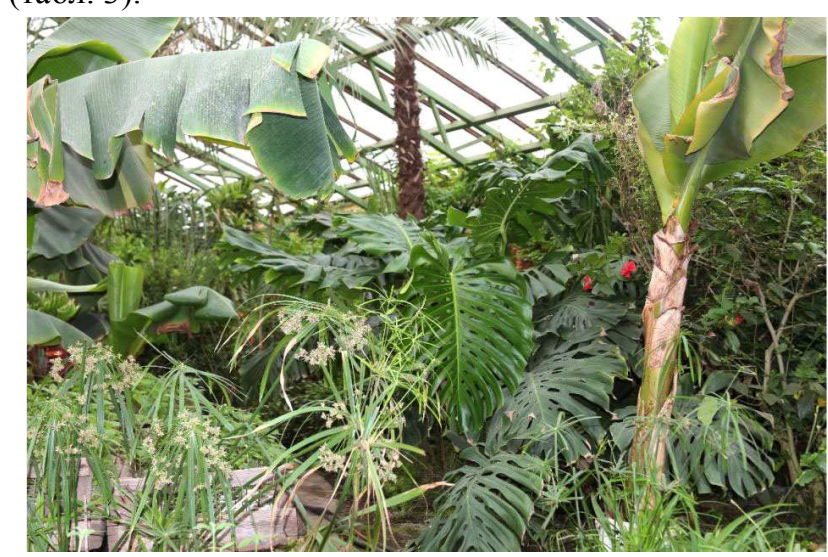

Рис. 1. Оранжерея Ботанічного саду "Поділля"

Досліджено, що рослини різних природних ареалів зростання розташовані в оранжереї хаотично, без дотримання певного порядку чи систематики. Види інтродуцентів, які $\epsilon$ в оранжереї ботанічного саду, різняться за відношенням до температури, прийнятної для їх нормального росту і розвитку, тому і розміщувати їх варто групами чи колекціями, наприклад: зона рослин тропіків, зона рослин субтропіків, зона рослин сухих субтропіків, зона рослин Середземномор'я та зона рослин Азії (табл. 3). У дендрарії ботанічного саду (понад 600 видів дерев, які можуть рости на відкритому грунті місцевості), який є серцем ботанічного саду, висаджено колекції багатьох видів дерев і чагарників. Рослини цих колекцій, які добре акліматизувалися зі Східної Свропи і Сибіру, а також континентальних районів Північної Америки, дають насіння та черенки, що можна висаджуються висадити у парниках і зимовому саду для наступної реалізації - серед населення, підприємств та на території ботанічного саду.

Табл. 2. Види рослин оранжереї зі зазначенням природного ареалу поширення

\begin{tabular}{|c|c|c|}
\hline $\begin{array}{l}\text { № } \\
\text { 3/ח }\end{array}$ & Назва виду (українська та латинська назви) & Природний ареал походження \\
\hline 1 & Абутілон Селло (Abutilon sellovianum Rgl.) & Тропіки і субтропіки обох півкуль \\
\hline 2 & Аспідістра висока (Aspidistra elatior Variegata) & Ліси Південного Китаю і Японії \\
\hline 3 & Холодок лікарський (Asparagus officinalis L.) & Центральна Америка, Австралія \\
\hline 4 & Бегонія великоквіткова (Begonia semperflorens) & Латинська Америка, Мексика, Шрі-Ланка, Африка \\
\hline 5 & Аукуба японська (Aucuba japonica) & Східна Азія, Японія \\
\hline 6 & Фатсія японська (Fatsia japonica) & Японія, Нова Зеландія \\
\hline 7 & Гонконзький кумкват (Fortunella hindsii) & Азіатсько-Тихоокеанський регіон \\
\hline 8 & Мандарин (Citrus reticulata) & Південь Китаю, Східна Азія \\
\hline 9 & Апельсин (Citrus sinensis) & Європа, Кавказ \\
\hline 10 & Лимон $($ Citrus $\times$ limon $)$ & Свропа, Америка \\
\hline 11 & Хурма звичайна (Diospyros lotus) & Свразія, Америка, Австралія \\
\hline 12 & Гібіск сирійський (Hibiscus syriacus) & Субтропіки та тропіки \\
\hline 13 & Спарманія (Sparmannia africana) & Мадагаскар, Південна Африка \\
\hline 14 & Самшит вічнозелений (Buxus sempervirens L.) & Африка, Мадагаскар, Мексика \\
\hline 15 & Алое деревоподібне (Aloe arborescens) & Африка, Мадагаскар, о. Сокотра \\
\hline 16 & Агава американська (Agave americana L.) & Північна і Центральна Америки \\
\hline 17 & Юка нитчаста (Yucca filamentosa) & Флорида, США, Мексика \\
\hline 18 & Трахикарпус Форчуна (Trachycarpus fortunei.) & Китай, Японія, М'янма та Індія \\
\hline 19 & Фінікова пальма (Phoenix canariensis) & Греція, о. Крит, Канарські острови \\
\hline 20 & Драцена канарська (Dracaena draco) & Південно-Східна Азія, Африка \\
\hline 21 & Філодендрон адамантовий (Philodendron adamantinum Mart. ex Schott) & Латинська Америка, Мексика, Австралія \\
\hline 22 & Фікус каучуконосний (Ficus elastica) & Африка, Середземномор'я \\
\hline 23 & Фікус Бенджаміна (Ficus benjamina) & Індія, Китай, Філіппіни \\
\hline 24 & Інжир (Ficus carica) & Середземномор'я, Близький Схід \\
\hline 25 & Хлорофітум хохлатий (Chlorophytum comosum) & $\begin{array}{l}\text { Південна Америка, Африка, о. Мадагаскар, Азія та } \\
\text { Австралія }\end{array}$ \\
\hline
\end{tabular}


26 Пеларгонія смугаста (Pelargonium zonale)

27 Пеларгонія великоквіткова (Pelargonium grandiflorum)

28 Герань пахуча (Pelargonium graveolens)

29 Нефролепіс (Nephrolepis cordifolia (L.) Presl)

30 Плектрантус кущовий (Plectranthus fruticosus)

31 Зефірантес Ліндлея (Zephyranthes lindleyana)

32 Сансевієрія (Sansevieria trifasciata)

33 Орхідея Катлея (Cattleya)

34 Плющ звичайний (Hedera caucasigena)

35 Бірючина Лігуструм (Ligustrum vulgare)

36 Пілея Кадієра (Pilea cadierei Gagnep.)

37 Розмарин лікарський (Rosmarinus officinalis)

38 Барвінок малий (Vinca minor L.)

39 Юстиція адатода (Justicia adhatoda)

40 Криптомерія японська (Cryptomeria japonica)

41 Банан японський (Musa basjoo)

42 Лавр благородний (Laurus nobilis)

43 Жакаранда мімозна (Jacaranda mimosifolia)

44 Традесканція (Tradescantia tricolor)

45 Пеперомія (Peperomia magnoliaefolia)

46 Кипарис звичайний (Taxodium distichum)

47 Павловнія повстяна (Paulownia tomentosa)

48 Роза бенгальська (Rosa bengalensis)

49 Більбергія (Billbergia pyramidalis)

50 Вріезія прекрасна (Vriesea splendens)

51 Гузманія (Guzmania)

52 Амариліс прекрасний (Amaryllis belladonna)

53 Клівія кіноварна (Clivia miniata)

54 Радермахера (Radermachera chinensis)

55 Олеандр звичайний (Nerium oleander)

56 Кринум азіатський (Crinum asiaticum)

57 Колеус Блюма (Coleus blumei)

58 Колоказія (Colocasia esculenta var. fontanesii)

59 Стрелітція королівська (Strelitzia reginae)

60 Ехеверія (Echeveria stolonifera)

61 Сциндапсус (Scindapsus)

62 Руелія клубнева (Ruellia tuberosa L.)

63 Ананас чубатий (Ananas comosus)

64 Авокадо (Persēa americāna)

65 Аглаонема крапчата (Aglaonema commutatum)

66 Калла ефіопська (Zantedeschia aethiopica)

67 Опунція Біджелоу (Opuntia bigelovii)

68 Гранат звичайний (Púnica granatum)

69 Гастерія бородавчата (Gasteria verrucosa Haw.)

70 Хавортія усічена (Haworthia truncata)

71 Сеткреазія пурпурна (Setcreasea purpurea)

72 Традесканція (Tradescantia spathacea $\mathrm{Sw}$ )

73 Іглиця Гірканський (Ruscus hypophyllum)

74 Каллістемон жовтий (Callistemon citrinus)

75 Молочай Миля (Euphorbia milii)

76 Кротон кодіеум (Codiaeum variegatum)

77 Цезальпінія (Caesalpinia pulcherrima)

78 Якобінія Поля (Jacobinia pohliana)

79 Традесканція (Tradescantia blossfeldiana)

80 Традесканція (Tradescantia virginiana)

81 Цереус перуанський (Cereus peruvianus)

82 Кордилина верхівкова (Cordyline terminalis)

83 Монстера коса (Monstera obliqua)

84 Бріофілум Мангіна (Bryophyllum manginii)

85 Каланхое (Kalanchoe blossfeldiana)

86 Каллізія Золотий вус (Callisia fragrans)

87 Солейролія (Soleirolia Gaud)

88 Валлота прекрасна (Vallota speciosa)

89 Бальзамін Уоллера (Impatiens walleriana)

90 Спатіфіллум (Spathiphyllum floribundum)

91 Виноград амурський (Vitis amurensis)

92 Виноград культурний (Vitis vinifera)

93 Виноград (Vitis vulpina)

94 Текома (Tecoma)
Східна Африка, Близький Схід

Близький Схід, південь Туреччини та Іраку

Помірна зона Північної півкулі

Азія, Америка, Австралія

Тропіки Африки, Азія, Австралія

Східна Африка

Африка, Мадагаскар і Азія

Тропічні ліси

Європа

Помірні та субтропічні ліси

Тропічні ліси всієї Землі

Західне Середземномор'я

Країни Південної Свропи

Мексика

Японія, Китай

Індія, Японія

Середземномор'я

Тропіки Бразилії

Мексика, Центральна Америка

Азія та Америка

Північна і Південна півкулі

Далекий Схід, Східна Азія

вся Свропа

Бразилія, Центральна Америка

Центр і південь америки

Венесуела, Бразилія

Капська провінція ПАР, Австралія

Південна Африка

Китай

Середземномор'я

Азія

Азія та Африка

Тропічні ліси Бірми, Гімалаїв

Південна Африка

Мексика

Тропічні Ліси Східної Азії

Східна Азія

Південна Америка

Свропа, Америка

Південно-Східна Азія

Південь Африки

Північна і Південна Америка

Південна Азія

Південна Африка

Південна Африка

Мексика

Тропічні Ліси Флориди

Азія, Середземномор'я

Австралія

Тропіки і субтропіки

Азія

Західна Європа

Тропічні ліси Бразилії

Аргентина

Аргентина

Центральна і Південна Америка

Азія, Америка, Австралія

Тропіки Африки

Центральний Мадагаскар

Австралія, Африка, Америка

Мексика, Америка

Тропічні регіони

Субтропіки Південної Африки

Субтропіки

Південна Америка, Східна Азія

Західна і Східна півкуля

Середня Азія

Америка

Тропіки і субтропіки

Scientific Bulletin of UNFU, 2020, vol. 30, no 1 
Табл. 3. Розподіл рослин оранжереї за кліматичними зонами

\begin{tabular}{|c|c|}
\hline $\begin{array}{c}\text { Назва групи рослин залеж- } \\
\text { но від природних ареалів } \\
\text { зростання }\end{array}$ & Назва родів (українська та латинська назви) \\
\hline Тропічні рослини & $\begin{array}{l}\text { Абутілон (Abutilon), Гібіск (Hibiscus), Алое (Aloe), Плектрантус (Plectranthus), Зефірантес } \\
\text { (Zephyranthes), Сансевієрія (Sansevieria), Каттлея (Cattleya), Пілея (Pilea Lindl), Банан (Musa), Пе- } \\
\text { перомія (Peperomia), Колоказія (Colocasia), Персея (Persea), Молочай (Euphorbia), Кордиліна } \\
\text { (Cordyline), Монстера (Monstera), Гелксина (Helxine), Текома (Tecoma) }\end{array}$ \\
\hline Субтропічні рослини & $\begin{array}{l}\text { Аспідістра (Aspidistra), Холодок (Asparagus), Бегонія (Begonia L.), Хурма (Diospyros), Спарманія } \\
\text { (Sparmannia), Агава (Agave), Фінікова пальма (Phoenix), Юстиція (Justicia), Губоцвіті (Lamiales), } \\
\text { Гузманія (Guzmania), Амариліс (Amaryllis), Колеус (Coleus), Стрелітція (Strelitzia), Ананас (Ana- } \\
\text { nas), Калла (Zantedeschia), Гастерія (Gasteria), Хавортія (Haworthia), Бріофілум (Bryophyllum), Ка- } \\
\text { ланхое (Kalanchoe), Валлота (Vallota), Бальзамін (Impatiens) }\end{array}$ \\
\hline Рослини сухих субтропіків & Клівія (Clivia), Ехеверія (Echeveria) \\
\hline $\begin{array}{c}\text { Середземноморські } \\
\text { рослини }\end{array}$ & $\begin{array}{l}\text { Кумкват (Fortunella), Цитрус (Citrus), Самшит (Buxus), Юка (Yucca), Драцена (Dracaena), Філо- } \\
\text { дендрон (Philodendron), Фікус (Ficus), Пеларгонія (Pelargonium L'Her), Бірючина (Ligustrum), Роз- } \\
\text { марин (Rosmarinus), Барвінок (Vinca), Лавр (Laurus), Традесканція (Tradescantia), Кипарис (Taxо- } \\
\text { dium), Шиповник (Rosa), Більбергія (Billbergia), Вріезія (Vriesea), Олеандр (Nerium), Опунція } \\
\text { (Opuntia), Сеткреазія (Setcreasea), Традесканція (Tradescantia), Каллістемон (Callistemon), Цезаль- } \\
\text { пінія (Caesalpinia), Якобинія (Jacobinia), Традесканція (Tradescantia), Цереус (Cereus), Калізія } \\
\text { (Callisia) }\end{array}$ \\
\hline Рослини Азії & $\begin{array}{l}\text { Аукуба (Aucuba), Фатсія (Fatsia), Трахикарпус (Trachycarpus), Хлорофітум (Chlorophytum), Жура- } \\
\text { вець (Geranium), Нефролепіс (Nephrolepis), Плющ (Hedera), Криптомерія (Cryptomeria), Павловнія } \\
\text { (Paulownia) або Адамове дерево, Радермахера (Radermachera), Кринум (Crinum), Сциндапсус } \\
\text { (Scindapsus), Руелія (Ruellia), Аглаонема (Aglaonema), Гранат (Granatum), Рускус (Ruscus), Ко- } \\
\text { діеум (Codiaeum), Спатіфіллум (Spathiphyllum), Цисус (Cissus) }\end{array}$ \\
\hline
\end{tabular}

На нашу думку, враховуючи велику кількість видів рослин, природний ареал походження яких є тропіки, ділянка, окремо відведена під цю групу рослин, буде найефектнішою за зовнішнім виглядом та розмірами. Незважаючи на те, що рослини тропіків мають безупинну вегетацію протягом усього року, необхідно уважно створювати необхідні умови для розвитку цієї групи рослин [3] (рис. 2).

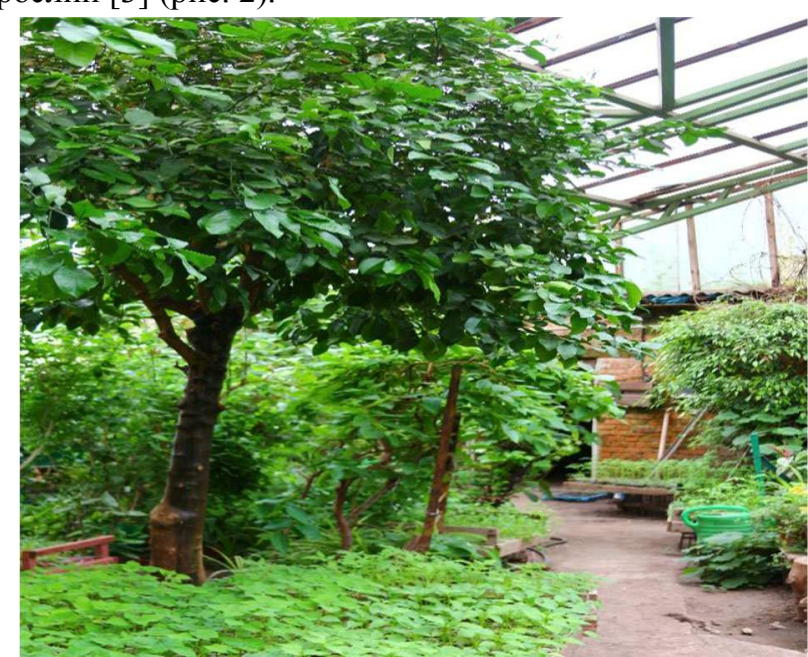

Рис. 2. Дерева та чагарники оранжереї

Відомим є той факт, що рослини тропічної групи звикли до постійно високої температури $\left(15-20^{\circ} \mathrm{C}\right)$ повітря у приміщенні, рівності дня і ночі та дуже високої (до 90 \%) вологості повітря, що є найважливішою умовою успішного їх існування у наших широтах. У разі дотримання всіх вимог декоративно квітнути і навіть плодоносити будуть всі інтродуковані рослини - від пальм, папоротей до інших тропічних рослин [3].

Досить часто садом, в якому чітко "виражені сезони", називають субтропічний зимовий сад. Стверджують, що найбільш декоративним та насиченим цвітінням рослин є сезон весни, що починається у лютому. Терміном 3 кінця жовтня по кінець січня декоративність рослин, порівняно з іншими сезонами є низькою.
Адже це період, коли рослини перебувають у стані спокою, а температура зимового саду повинна знизитися до $10-12{ }^{\circ} \mathrm{C}$ [3]. Тому доцільною $є$ наявність в оранжереї таких субтропічних рослин: алокація, арека, катеху, диффенбахія, пандорея, сансевієрія, сінгоніум тощо, які будуть цікавими для відвідувачів незалежно від сезону. Активно квітувати субтропічні рослини починають із березня, що в рази збільшує прихід відвідувачів до оранжереї.

Найпопулярнішими представниками сухих субтропіків є сукуленти, рослини, що мають властивість накопичувати у своїх листках велику кількість вологи i життєво необхідних речовин. Що стосується вимог до приміщення, в яких сукуленти мають ростутьрости, то влітку там повинно бути жарко гаряче, а в зимовий період - сухо і прохолодно.

Аналізуючи асортимент оранжереї, встановлено, що рослини сухих субтропіків представлені лише декількома видами, тому обов'язковим є поповнення колекції сукулентів і кактусів в оранжереї, представники яких починають цвісти з настанням весни. Серед великої різноманітності видів $\epsilon$ й такі, які в природі живуть на вулканічних породах у напівпустелях. Можна створити в оранжереї цікаві композиції у вигляді флораріумів із сукулентів (спеціальних пристроїв зі скла або прозорого пластику, всередині якого поміщені флористичні композиції) чи окремо виділити ділянку під кактусарій, де буде представлено колекцією кактусів, розміщених в умовах, що нагадують природні умови батьківщини цих рослин.

Вибір рослин для середземноморської групи дуже великий. Адже більшість рослин цієї групи нормально росте і розвивається в прохолодних у зимовий час садах. Що стосується весняного періоду їх росту і розвитку, то до осені їм потрібно тепло та сонце. У зимній період, коли в багатьох рослин оранжереї починається період спокою, вони скидають листя i потребують обов'язкової обрізки. Вимоги до приміщення у цей період: світло і прохолода [3]. 
Рослини Азї̈ є невибагливими, порівняно з рослинами інших груп, і можуть перебувати як у теплий, так і в холодний зимовий час в оранжереї. Позитивним аспектом $\epsilon$ невибагливість їх у догляді. Для росту і розвитку достатньо дотримання температурних режимів.

Рослини, природним ареалом поширення яких $є$ різні куточки Земної поверхні, завдяки таким властивостям, як адаптація й екологічна пластичність, можна використати для створення різноманітних композицій у зимових садах чи оранжереях. Вибір рослин для зимового саду є широким.

\section{Висновки:}

1. На території оранжереї Ботанічного саду "Поділля" зростає 94 види рослин, віднесених до 88 родів та 44 родин.

2. Рослини різного природного ареалу походження розташовані в оранжереї хаотично, без дотримання певного порядку чи систематики.

3. Рекомендуємо всі рослини оранжереї розподілити за групами, створити такі собі колекції тропічних рослин, субтропічних рослин, рослин сухих субтропіків, рослин Середземномор'я та рослин Азії.

4. Враховуючи малу кількість представників рослин сухих субтропіків в оранжереї ботанічного саду, обов'яз- ковим $є$ поповнення колекції сукулентів та створення флораріуму і кактусарію.

\section{References}

1. Cherniak, V. M., Prokopchuk, V. M., \& Monarkh, V. V. (2018). Some prospects of growing and use of Shina aster aor space greening in Podillia zone. Scientific Bulletin of UNFU, 28(7), 22-26. https://doi.org/10.15421/40280704

2. Ermolova, E. V. (2010). Sadovo-parkovoe yskusstvo. Volhohrad: Yn-Folyo, 192 p. [In Russian].

3. Kryzhanivska, N. Ia. (2015). Osnovy landshaftnoho dyzainu. Kyiv: Lira-K, 218 p. [In Ukrainian].

4. Kucheriavyi, V. P. (2017). Landshaftna arkhitektura. Lviv: Novyi Svit-2000, 521 p. [In Ukrainian].

5. Monarkh, V. V. (2019). Biological and ecological characteristics of dendroflora of the Podillia botanical garden of Vinnytsia national agrarian university. Agricultire and Forestry: collection of scientific works of VNAU, 13, 228-238. [In Ukrainian].

6. Roi, V. (2019). Khvoinye rastenyia - hlavnoe ukrashenye zymneho sada. Krasota y polza Neskuchnyi sad: ezhemesiachnyi praktykum sadovoda, 1/2, 14-17. [In Russian].

7. Votinov, M. A. (2011). Konspekt lektsii $z$ dystsypliny "Landshaftnyi dyzain". Kharkiv: KhNAMH, 98 p. [In Ukrainian].

8. Zymnyi sad Perspekta kak ynvestytsyia. (2019). Landshaft y arkhytektura: zhurnal o landshaftnoi arkhytekture y dyzaine, 1, 68-69. [In Russian].

V. V. Monarkh

Vinnytsia National Agrarian University, Vinnytsia, Ukraine

\section{ANALYSIS OF THE ASSORTMENT OF PLANT ORANGERY OF THE PODILLIA BOTANICAL GARDEN OF VINNYTSIA NATIONAL AGRARIAN UNIVERSITY}

The Vinnytsia region has a research and cultural and educational institution, which constantly collects flora collections for the purpose of its study, preservation, cultivation and acclimatization in the greening of the city, search and selection of plants that are promising for creating green spaces and work on conservation of the gene pool of the plant world. This facility is the Podillya Botanical Garden, located in the Vinnytsia National Agrarian University. It is proved that the place set aside for landscaping is a room in which a limited area of exotic plants, combined with water devices and small architectural forms is a greenhouse of the Botanical Garden "Podillya" of Vinnytsia National Agrarian University. The main importance of which is not only the prolongation of human stay in the natural environment, regardless of the time of year and air temperature, but also the reproduction and introduction of plant species in other climatic zones. For the first time, a modern assessment of the assortment of greenhouse plants at the Podillya Botanical Gardens of Vinnytsia National Agrarian University was carried out, according to which there are 44 families, 88 genera and 94 plant species in the greenhouse. It has been investigated that the plants of different climatic zones are located in the greenhouse in a chaotic manner without following a certain order or systematics. Plants that grow in the greenhouses of the botanical garden, depending on their relationship to the temperature regime of characteristic climatic zones, we suggest to place groups or collections: tropical, subtropical, dry subtropics, plants of the Mediterranean, plants of Asia. Given the small number of representatives of dry subtropics in the Botanical Garden greenhouse, it is mandatory to replenish the succulents collection and create a florarium and cactusarium. The main component of the greenhouse is plants, which require different conditions of temperature in the room. In the winter garden used plants brought from different countries. Therefore, it is worth highlighting certain groups of plants that belong to a particular climate zone. As a result, the indoor climate of the plant life in nature should be maintained indoors.

Keywords: winter garden; introduction; habitat; inventory; facility. 